\title{
UNION ELECTIONS UNDER THE LMRDA
}

Congress enacted the Labor-Management Reporting and Disclosure Act of $1959^{1}$ (LMRDA) primarily "to ensure union democracy," members' rights to participate in the union's election process. ${ }^{3}$ Although state law had provided some protection for these rights, Congress concluded that this law was inadequate. ${ }^{4}$ As a result, Title IV ${ }^{5}$ of the Act gives all members in good standing the right to vote, to nominate candidates, to run for and hold office, subject only to reasonable qualifications uniformly imposed. ${ }^{0}$ Title IV also regulates the frequency with which union elections must be conducted, ${ }^{7}$ requires distribution of campaign literature and access to membership lists, and prohibits utilization of union funds to promote individuals' candidacies." Title $I^{10}$ provides a general guarantee of "equal rights and privileges within [the union] to nominate candidates, [and] to vote in elections. . . ."11

To enforce these rights and duties Congress provided different remedies for each Title. If, after the election has been held, a union member alleges a violation of Title IV, he must file a complaint with the Secretary of Labor. ${ }^{12}$ The

1. 73 Stat. 519 (1959), 29 U.S.C. \$§ 401-531 (Supp. V, 1964).

2. S. Rep. No. 187, 86th Cong., 1st Sess. 2 (1959).

3. "It needs no argument to demonstrate the importance of free and democratic union elections." S. REP. No. 187, 86th Cong., 1st Sess. 20 (1959) ; H.R. REP. No. 741, 86th Cong., 1st Sess. 15 (1959). "The Government which gives unions this power has an obligation to insure that the officials who wield it are responsive to the desires of the men and women whom they represent." S. REP. No. 187, 86th Cong., 1st Sess. 20 (1959).

4. In discussing state regulation of union elections, Senator Kennedy said, "I do not think state law provides adequate remedies in that field." 105 CoNG. Rec. 6487 (1959).

5. 73 Stat. 534 (1959), 29 U.S.C. $\S 881-83$ (Supp. V, 1964). The provisions of Title IV comprise $\$ \$ 401-03$ of the LMRDA.

6. 73 Stat. 532 (1959), 29 U.S.C. $\$ 481$ (e) (Supp. V, 1964).

7. 73 Stat. 532 (1959), 29 U.S.C. $\$ 481$ (a), (b) (Supp. V, 1964).

8. 73 Stat. 532 (1959), 29 U.S.C. § 481 (c) (Supp. V, 1964).

9. 73 Stat. 532 (1959), 29 U.S.C. \& $481(\mathrm{~g})$ (Supp. V, 1964).

10. 73 Stat. 522-23 (1959), 29 U.S.C. $\$ \$ 411-15$ (Supp. V, 1964). The provisions of Title I comprise $\$ \S 101-05$ of the LMRDA.

11. Section 101(a) (1) of the LMRDA. 73 Stat. 522 (1959), 29 U.S.C. \& 411 (a)(1) (Supp. V, 1964). The bill was subsequently enacted as the LMRDA was drafted without a bill of rights (Title $I$ as enacted). It was during the debate in the Senate that Title I was superimposed as an afterthought with no effort to reconcile its election provisions with the other election provisions of the bill. 105 CoNG. REc. 6469-93 (1959). The only guidance for reconciling these two provisions is a statement by Senator Kennedy that the bill of rights "must be read in conjunction with the rest of the bill." 105 CoNG. REC. 6720 (1959). For a detailed discussion of the legislative history of the bill of rights sce Sherman, The Individual Member and the Union: the Bill of Rights Title in the LaborManagement Reporting and Disclosure Act of 1959, 54 Nw. U.L. Rev. 803 (1960); sec also the discussion in Mamula v. 'United Steelworkers of America, 304 F.2d 108, 110 (3rd Cir. 1962).

12. 73 Stat. 534 (1959), 29 U.S.C. \& 482 (a) (Supp. V, 1964). The third sentence of $\S 403$ states that, "the remedy provided by this title for challenging an election already 
Secretary then must sue in a federal court when there is probable cause to believe a violation has occurred. ${ }^{13}$ The Secretary has no authority to sue before the election. ${ }^{14}$ The words of Title IV are unclear about whether an individual union member can obtain any relief before the election. ${ }^{15}$ However, if a violation of Title $I$ is alleged a union member does not have to wait until after the election, nor does he have to depend on the Labor Department. He can sue for pre-election relief in a federal district court. ${ }^{16}$

These titles present extreme difficulties. Not only are the substantive rights vaguely defined, but the general guarantees of Title I overlap with the more specific provisions of Title IV. ${ }^{17}$ This overlap is especially troublesome because the titles contain different enforcement schemes. These wealinesses in the statute confront a court when a plaintiff seeks pre-election relief alleging conconducted shall be exclusive" 73 Stat. 534 (1959), 29 U.S.C. \& 483 (Supp. V, 1964). Those federal courts which have been faced with post-election suits brought by individuals to set aside an election because of a violation of Title IV rights have quiclly dismissed for lack of jurisdiction. Mamula v. United Steelworkers of America, 304 F.2d 103 (3rd Cir. 1962); Gammon v. International Ass'n of Mlachinists, 199 F. Supp. 433 (N.D. Ga. 1961) ; Coleman v. Brotherhood of Railway and Steamship Clerks, 228 F. Supp. 276 (S.D.N.Y. 1964); Myers v. Operating Engineers, 45 L.RR.MC. 3045 (E.D. Mfich. 1960). See also the statement of Stewart, J., concurring in Calhoon v. Horvey that, "as to federal courts it is certainly arguable that recourse through the Secretary of Labor is the exclusive remedy only after the election has been held." 379 U.S. 134, 146 (1964).

13. 73 Stat. 534 (1959), 29 U.S.C. § 482(b) (Supp. V, 1964).

14. Section 402 of Title IV makes it clear that a union member cannot go to the Secretary of Labor for pre-election relief. Section $402(c)$ permits the courts to grant relief only in suits brought by the Secretary when a violation of $\S 401$ affected the outcome of an election, or when an election was not held within the time preseribed by § 401. Similarly § 402(a) assumes that an election has taken place before the Secrelary may intervene since it provides that the challenged election shall be presumed valid pending a final decision thereon. 73 Stat. 534 (1959), 29 U.S.C. $\S 482$ (Supp. V, 1964). The only two courts which have considered the question of pre-election suits by the Secretary have concluded that these are not authorized by the statute. Johnson v. San Diego Waiters \& Bartenders Union, 190 F. Supp. 444 (S.D. Cal. 1961); Jackson v. National Marine Eng. Ben. Ass'n, 221 F. Supp. 347, 349 (S.D.N.Y. 1963).

15. The second sentence of $\S 403$ provides that "existing rights and remedies to enforce the constitution and bylaws of a labor organization with respect to elections prior to the conduct thereof shall not be affected by the provisions of this title." 73 Stat. 534 (1959), 29 U.S.C. \& 483 (Supp. V, 1964).

16. Section 102 provides, "Any person whose rights secured by the provisions of this subchapter have been infringed by any violation of this subchapter may bring a civil action in a district court of the United States for such relief (including injunctions) as may be appropriate. Any such action against a labor organization shall be brought in the district court of the United States for the district where the alleged violation occurred, or where the principal office of such labor organization is located." 73 Stat. 523 (1959), 29 U.S.C. \& 412 (Supp. V, 1964).

17. For a discussion of the overlap between Title I and Title IV substantive rights see Smith, The Labor-Management Reporting and Disclosure Act of 1959, 46 VA. L REv. 195, 224 (1960); see also Daniels, Union Elections and the Landrum-Griffin Act, 13Tr ANN. N.Y.U. CONF. ON LABOR, 317, 327-30 (1960). 
duct which only arguably violates the vague provisions of Title $I$, but which clearly violates the more specific provisions of Title IV. A court could talkc jurisdiction to grant relief either by broadly construing the substantive provisions of Title I or by construing the remedial provisions of Title IV to allow pre-election suits. Conversely, the court could deny jurisdiction by finding that the plaintiff alleged a violation of Title IV, not Title I, and then by refusing to find a pre-election remedy in Title IV. The choice between these alternative procedural decisions largely determines the effectiveness of the Act, since the second alternative forces the union member to wait until after the election before he can sue, and leaves him with very little effective protection.

In a recent case, Calhoon v. Harvey, ${ }^{18}$ the Supreme Court made exactly this choice. In Calhoon the bylaws of the defendant local union provided that a member could nominate only himself for any union office. The constitution of the national union provided that all nominees for office must have been union members for at least five years and must have served 180 days or more at sea on vessels covered by collective bargaining agreements with the national organization in two of the three years preceding nomination. Nominees for President must have served as a full time paid elected official of an organization affiliated with the national body. The effect of these provisions was that although every member had the right to nominate, the only nominations which were effective were those by members who also met the eligibility requirements. Plaintiff Harvey, who did not satisfy the requirements, alleged that his Title I right to "equal rights and privileges ... to nominate candidates"10 had been violated. He invoked the jurisdiction of the federal district court under Title $I$, and sought to enjoin an impending union election. ${ }^{20}$ The district court dismissed the complaint, ${ }^{21}$ holding that plaintiff did not allege a Title I violation, but only a Title IV violation for which there was no pre-election relief. Following reversal by the Court of Appeals, ${ }^{22}$ the Supreme Court reinstated the District Court's order. ${ }^{23}$

The majority of the Court refused to consider any of the candidacy requirements in determining whether the right to nominate had been infringed. ${ }^{24}$ Once the majority removed this consideration it held that the self-nominating rule did not violate Title I, since the self-nominating rule applied equally to all union members. ${ }^{25}$ Then the majority held that the Title IV violations alleged could be remedied only through post-election "administrative and judicial proce-

18. 379 U.S. 134 (1964).

19. 73 Stat. 522 (1959), 29 U.S.C. $\$ 411$ (a) (1) (Supp. V, 1964); see Brief for Rcspondent, pp. 19-21, Calhoon v. Harvey, 379 U.S. 134 (1964).

20. See $\S 102,73$ Stat. 523 (1959), 29 U.S.C. $\S 412$ (Supp. V, 1964), conferring jurisdiction.

21. 221 F. Supp. 545, 550 (S.D.N.Y. 1963).

22. 324 F.2d 486 (2d Cir. 1963).

23. 379 U.S. 134 (1964).

24. 379 U.S. at 140 .

25. 379 U.S. at 139. 
dures."26 Nothing in the language of the Act compelled either holding, and the majority based its decision on its view that Congress wanted to "utilize the special knowledge and discretion of the Secretary of Labor"27 in order to prevent individuals from "block[ing] or delay[ing] union elections by filing federal court suits for violations of Title IV."28

This Note will argue that the Court decided Calhoon wrongly because it was mistaken in its major premises. First, Congress intended to give only a restricted role to the Secretary of Labor. And second, Congress' main concern was not with protecting the union against the individual, but with protecting the individual against the union. In effect the Supreme Court reversed the Congress by giving priority to the union's institutional stability. Not only did the Court refuse to protect the individual members, but it reduced the protection to a level lower than before the LMRDA.

Congress gave the Secretary of Labor responsibility in post-election cases for the limited reasons that he could best consolidate all post-election suits and supervise re-elections when necessary. ${ }^{29}$ Congress feared that multiple individual suits would unduly interfere with the union's operation after an election. Congress also realized that courts could not adequately supervise new elections. ${ }^{30}$ None of the functions assigned to the Secretary - investigation, prosecution, and supervision of judicial relief - indicate a congressional belief in his "special knowledge." 31 Nor do they indicate that Congress wanted to de-

26. 379 U.S. at 141 . While the complaint in Calhoon only claimed a Title I violation, it could have been amended under the liberal amendment procedures of the Federal Rules to include a Title IV claim had the Supreme Court concluded that jurisdiction existed under Title IV. See, e.g., Stern v. Beer, 200 F.2d 794 (6th Cir. 1952); Christensson v. Hogdal, 199 F.2d 402 (D.C. Cir. 1952). See generally 3 M Toore, Federal Practice If 15.09, at 945 (1964).

27. 379 U.S. at 140.

28. Ibid.

29. However, in the enforcement scheme as set out by Congress the courts were to have the primary adjudicatory responsibility. Unlike the NLRA the LMIRDA does not permit the Secretary of Labor to adjudicate alleged violations but provides that if the Secretary finds probable cause to believe a violation has occurred, "he shall . . . bring a civil action." 73 Stat. 534 (1959), 29 U.S.C. § 482(b) (Supp. V, 1964). Also the LMRDA gives the Secretary no general rulemaking power which would be applicable to eligibility cases such as Calhoon. Title IV gives the Secretary the power to make rules and regulations regarding only the removal of officers guilty of serious misconduct. 73 Stat. 533 (1959), 29 U.S.C. \& 481(i) (Supp. V, 1964). The courts had already demonstrated in the pre-statutory law that they were competent in adjudicating union election disputes. See, e.g., Lacey v. O'Rourke, 147 F. Supp. 922 (S.D.N.Y. 1956) ; Dusing v. Nuzzo, 263 App. Div. 59, 31 N.Y.S.2d 849 (1941) ; Sibilia v. Western Electric Employees Ass'n, 142 N.J. Eq. 77, 59 A.2d 251 (1948). See generally Summers, Judicial Regulation of Union Elections, 70 YALE L.J. 1221 (1961).

30. See, e.g., statement by Professor Cox, Hearings on S. 505 bejore the Subcommillec of Labor of the Senate Conmittee on Labor and Public IWelfare, 86th Cong., 1st Sess. 119,133 (1959).

31. The rejection of the NLRB as an administrator of the election provisions of the LMRDA indicates that expertise was not the dominant criteria. See generally Hearings 
pend on the Secretary's "discretion" in these election cases.32 And certainly nothing in the legislative history should have been interpreted to allow these limited functions of the Secretary to supplant the individual's only effective relief, relief before the election. ${ }^{33}$

Unlike the pre-election case in which a successful suit prevents the defendants from taking office, the post-election case ${ }^{34}$ allows those illegally in office to

on S. 505 before the Subcommittee of Labor of the Senate Committec on Labor and the Senate Committee on Labor and Public Welfare, 86th Cong., 1st Sess. (1959).

32. When Title I was first proposed by Senator McClellan as an amendment to the remainder of the bill, it provided for civil enforcement of Title I rights through suits by the Secretary of Labor. See $\S 103$ of the McClellan Amendment, 105 CoNo. REc. 6476 (1959). The Kuchel Amendment (enacted as $\$ 102$ ) permitted individual suits by union members. When Senator Kuchel introduced this amendment, he stated, "Here is one of the major changes in the proposal. The Amendment of the Senator from Arkansas provided that the Secretary of Labor might, on behalf of the injured or aggrieved member, have the right to litigate the alleged grievance and to seek an injunction or other relief. We believe that giving this type of right to the aggrieved employee member himsclf is in the interest of justice." 105 CoNG. REc. 6720 (1959).

33. Also, the Secretary of Labor is a political figure who informally settles bargaining disputes between unions and employers. If he finds himself investigating the election of union officers and at the same time participating with those officers in the collective bargaining process, neither his statutory duty under $\S 402$ of the LMRDA nor his bargaining responsibility will be fulfilled.

34. Throughout this Note a distinction is made between post-election and pre-election suits. The statute itself implies that this distinction is indispensable in the interpretation of its jurisdictional provisions. The third sentence in $\S 403$ makes the remedy provided in Title IV exclusive for challenging an election "already conducted." Such a suit is obviously different from the suit described by the second sentence in $\S 403$ : "rights . . . with respect to elections prior to the conduct thereof." 73 Stat. 534 (1959), 29 U.S.C. $\S 483$ (Supp. V, 1964).

Not only do both the statutory language and the legislative history indicate that different fora and different procedures might be available in a pre-election as opposed to a post-election suit, but this distinction also existed in state law regulating urion elections prior to the enactment of LMRDA. In this state law, against which Title IV was enacted, "the willingness of the courts to intervene, the form of the remedy provided, and the effectiveness of judicial intervention" depended upon whether the suit was brought before the election had taken place. Summers, Judicial Regulation of Union Elcctions, 70 YALE L.J. 1221, 1244 (1961).

Most cases may be easily classified as pre-election or post-election depending upon the timing of judicial intervention and the remedy sought. One difficult situation arises when plaintiff seeks initially to enjoin an election but the court does not consider the case until after the election has been held. For example, the plaintiff may lose his right to a temporary injunction by failing to post the bond which is a condition precelent to the injunction; and the election may take place before the case is heard on the merits. See Gammon v. International Ass'n of Machinists, 199 F. Supp. 433 (N.D. Ga, 1961). Also, the district court may deny the temporary injunction. The election may take place, and then in a subsequent hearing the court may discover violations of the Act. Sce Mamula v. United Steelworkers of America, 304 F.2d 108 (3rd Cir. 1962), cert. denicd, 371 U.S. 823 (1963). The only relief which the court can grant in these cases is to set aside the election and order a new one to take place, since the motion for an injunction has obviously become moot by the time the court hears the case. See Colpo v. Highway 
enjoy its benefits during the period of litigation. ${ }^{36}$ The length of time required to obtain post-election relief under the statute makes this disadvantage especially serious. In one case, for example, the challenged election took place December $10,1960 .{ }^{36}$ On January 12,1963 the district court held that the complaining union member had been unlawfully excluded from running for office. By that time the defendants had controlled the union for almost the entire term to which they were illegally elected. ${ }^{37}$

This extensive delay results partly from the procedural requirements which the statute imposes upon the union member seeking post-election relief. Before filing a complaint with the Secretary of Labor, he must have exhausted all the remedies available within the union, or he must have pursued them for three months without receiving a final decision. ${ }^{38}$ The Secretary of Labor then has sixty days to investigate the allegations and to bring suit if he finds probable cause to believe a violation has occurred. ${ }^{39}$ If the Secretary discovers violations not alleged by the complaining union member, a second round of exhaustion may be required before suit can be brought on the additional matters. 10 Once

Truck Drivers \& Helpers Local 107, 305 F.2d 362 (3rd Cir.), cert. denied 371 U.S. 890 (1962). The court should treat these cases as post-election suits notwithstanding the fact that the complaint was filed prior to the election and the complainant sought initially to enjoin the election. On the other hand a suit ought to be classified as preelection where plaintiff seeks judicial aid to prevent irregularities from occurring in any part of the election process. This classification would, for example, apply to a suit to impound ballots already cast to prevent irregularities in the counting process. See Beckman v. International Ass'n of Bridge Workers, 314 F2d 848 (7th Cir. 1963).

35. Section 402(a) provides that the "challenged election shall be presumed valid pending a final decision thereon." 73 Stat. 534 (1959), 29 U.S.C. § 482(a) (Supp. V, 1964).

36. Goldberg v. Amarillo General Drivers, Warehousemen \& Helpers Loal 577, 214 F. Supp. 74 (N.D. Tex. 1963).

37. The statute requires local unions to conduct elections once every three years, and internationals are required to conduct them every five years. 73 Stat. 532 (1959), 29 U.S.C. § 481 (b), (c) (Supp. V, 1964).

38. 73 Stat. 534 (1959), 29 U.S.C. \& 482(a) (2) (Supp. V, 1964). Congress described the purpose of the exhaustion provisions as being the preservation of "a maximum amount of independence and self-government by giving every international union the opportunity to correct improper local elections." S. REp. No. 187, 86th Cong., 1st Sess. 21 (1959). The courts have not yet had an opportunity to indicate how strictly the exhaustion requirement would be enforced in the context of a complaint filed with the Secretary of Labor under Title IV. The one district court which considered this question in any detail concluded that exhaustion would not be required where the internal complaint was to be heard by those very people against whom the complaint was to be made. Wirtz v. Local 125, Int'l Hod Carriers, 231 F. Supp. 590, 595 (N.D. Ohio 1964).

39. 73 Stat. 534 (1959), 29 U.S.C. \& 482(b) (Supp. V, 1964). In Wirtz v. Local 611, Int1 Hod Carriers, 229 F. Supp. 230 (D. Conn. 1964), the court held that where the Secretary waited 62 days because the 60th day was a Sunday and the 61st day was Veterans Day, when the clerk's office was closed, the suit was timely.

40. Even if no complaint at all is filed by a union member, the Secretary of Labor has the authority to conduct an investigation of a union election and to issue a subpona duces tecum in connection with such an investigation. Wirtz v. Local 191, Int'l Bhd. of Teamsters, 321 F.2d 445 (2d Cir. 1963); Wirtz v. Local 125, Int'l Hod Carriers, 231 F. 
the Secretary files his complaint, traditional delaying tactics in pre-trial discovery, ${ }^{41}$ trial, and appeal may be utilized for delay by union officers.

The length of time involved in this process may preclude the relief to which the union member is entitled. The terms of those officers whose election is being challenged may have expired since terms of local officers are limited to three years. ${ }^{42}$ In such cases intervening elections may have been conducted. Even if the terms have not expired, it is unclear whether the officers elected in an election ordered by the court serve the remainder of the term begun by those illegally in office, or whether the new officers are entitled to serve for a full term.

Another disadvantage of post-election relief is that the LMRDA imposes greater burdens upon the plaintiff. ${ }^{43}$ For example, section 402 (c) permits a court to set aside an election only if it can be shown by a preponderance of the evidence that a violation of Title IV "may have affected the outcome."44 Evidence to demonstrate that the outcome of the election has been affected may be very difficult for a non-officer plaintiff to obtain. ${ }^{45}$ And for some violations,

Supp. 590 (N.D. Ohio 1964). This authority comes from $\$ 601(a)$ of the LMRDA, at general investigatory provision. 73 Stat. 539 (1959), 29 U.S.C. \& 521 (Supp. V, 1964). A fortiori the Secretary can investigate matters not alleged in the union member's complaint as well as those specifically alleged. However, authorization to investigate is not authorization to litigate. This raises the question of whether the Secretary may include in the complaint he files with the district court matters which his investigation uncovered but which the union member never alleged. One district court permitted the Secretary to include in his complaint matters not alleged by the union member, Goldberg v. Trico Workers Union, 53 L.R.R.M. 2875 (W.D.N.Y. 1963), concluding that to require duplication of exhaustion would seriously impair the effectiveness of the statutory schemc. A second court, however, has reached a contrary result in a slightly different case. Wirtz v. Local 125, Int'l Hod Carriers, 231 F. Supp. 590 (N.D. Ohio 1964).

41. Goldberg v. District Lodge 70, I.A.M., 51 L.R.R.M. 2036 (D. Kan. 1962). Bul cf. Wirtz v. Local 30, Int'l Union of Operating Engineers, 34 F.R.D. 13 (S.D.N.Y. 1963), holding that the Secretary of Labor does not have to appear personally for a deposition, absent a showing of injustice.

42. See note 37, supra.

43. A study by Professor Summers of pre-LMRDA decisions in union election cases in the New York State courts indicates that this greater burden inheres in the nature of post-election relief. If a court grants post-election relief, it imposes upon the union not only the costs of a new election, but more importantly, the internal disruption caused by the lack of legitimatized leadership and the turmoil of another and more bitter campaign.

Summers, Judicial Regulation of Union Elections, 70 YaLE L.J. 1221, 1244-45 (1961).

44. 73 Stat. 534 (1959), 29 U.S.C. \& 482(c) (Supp. V, 1964). More than 25 per cent of the complaints filed with the Secretary of Labor during the fourth year of the Act's operation were dismissed for failing to satisfy this test. U.S. Dep't of Labor, Sumlmary of Operations 1964, Labor Management Reporting and Disclosure Act 6 (1964).

45. For example, if plaintiff cannot observe the ballot box continuously, he nay find it exceedingly difficult to prove that it has been stuffed. Even if the tally indicated that 1200 votes had been cast and that plaintiff was defeated by a vote of 800 to 400 in a union with a total membership of 2500 , and plaintiff can show that 250 ballots cast 
it will be difficult, if not impossible, to show that the election would have been affected, for example, by the use of union money to promote an individual's candidacy. ${ }^{40}$ Even if the election outcome would not have been different, an aggrieved plaintiff might deserve relief. An illegally excluded candidate who can prove only minority support, may want to show that there is a functioning minority which is part of the union's political structure. ${ }^{77}$ Denying his relief hinders the gradual development of opposition parties. ${ }^{48}$

The relative ineffectiveness of post-election relief did not escape congressional notice, ${ }^{49}$ and Congress clearly intended to preserve pre-election relief, at least in state courts. When the bill was introduced in the Senate, it provided that post-election suits brought by the Secretary would be the exclusive method of enforcing an individual's rights. ${ }^{50}$ Neither state nor federal courts would have jurisdiction to give any pre-election relief. Opponents of this bill argued that though its purpose was to increase the protection available to union members, the bill would actually reduce protection since pre-election remedies were the only effective ones, and these could be obtained under existing state law but not under the bill. ${ }^{51}$ As a result the bill was amended to allow at least

in his favor were destroyed, this may not support an inference that 150 other ballots were similarly disposed of, thus affecting the election. See, e.g., Wirtz v. Loal 11, Int'l Hod Carriers, 211 F. Supp. 408 (W.D. Pa. 1962), for a case illustrating the dificulties of proof facing a plaintiff.

46. 73 Stat. 532 (1959), 29 U.S.C. § 481 (g) (Supp. V, 1964).

47. See Stewart, J., concurring in Calhoon v. Harvey, 379 U.S. 134, 146, n. 7 (1964). If the vote count gives the majority party 800 votes and the dissenters 200 , in a union with a membership of 1500 , the dissenters will have no remedy even if 500 of their votes were not counted. However this would prevent an opposition party from showing its true strength in one election which could reduce its chances of prevailing in subsequent elections.

48. There are still other difficulties with the post-election remedy which may prevent effective relief in certain cases. Suppose, for example, the Secretary can show that the votes were miscounted and that the candidate who had been declared the loser had in fact received a majority of votes. The Secretary should be able to certify the eandiclate who received the greatest number of votes as the winner. However, the statute does not speak of such a remedy; it only provides that the old election shall be set aside and a new one conducted. 73 Stat. 534 (1959), 29 U.S.C. § 482(c) (Supp. V, 1964).

49. See, e.g., the statement of Professor Cox in referring to pre-election remedies as "often more effective than a challenge to the validity of an election after it has been held." Hearings on S.505 before the Strbcommittee of Labor of the Senate Commillee on Labor and Public Welfare, 86th Cong., 1st Sess. 135 (1959).

50. The only remedies provided by the Elections Title (Title IV as enacted) involved the Secretary of Labor. Also the original bill had nothing equivalent to the bill of rights in Title I of the LMRDA as enacted. See text of S. 505, 86th Cong., 1st Sess. (1959).

51. See, e.g., ACLU, A Labor Union "Bill of Rights" - Dearocracy m Lazon Unions - The Kennedy-Ives Bril (Sept., 1958); see also statements of Professor Summers, Hearings on Union Financial and Administratize Practices and Proccdures before the Subcommittee on Labor of the Senate Committee on Labor and Public Welfare 594, 613, 85th Cong., $2 d$ Sess. (1958). 
some of the issues which could be raised by the Secretary in post-election suits to be raised by individuals in state pre-election suits. ${ }^{.2}$

The Court, in Calhoon, completely ignored these indications that Congress did not intend to foreclose pre-election remedies. Instead when the majority denied plaintiff pre-election relief it interpreted the inconclusive words of the statute to thwart its overriding purpose, and at least in the case of pre-election state remedies removed a protection which existed before the Act. ${ }^{63}$ The correct decision would have been to require the district court to determine the merits of the case before the union's election. Jurisdiction of the federal district court could have been founded either upon a construction of the remedial provisions of Title IV to allow pre-election suits, or a broader construction of the substantive rights in Title I, which clearly does allow pre-election suits.

Neither the lack of a specific pre-election provision, nor the existence of post-election administrative procedures necessarily bars the federal courts' preelection jurisdiction to enforce Title IV rights. 28 U.S.C. section 1337, providing that:

The district courts shall have original jurisdiction of any civil action or proceeding arising under any Act of Congress regulating commerce or protecting trade and commerce against restraints and monopolies, ${ }^{t 4}$

52. The second sentence of what is now $\S 403$ of the LMRDA was added to provide, "existing rights and remedies to enforce the constitution and bylaws of a labor organization with respect to elections prior to the conduct thereof shall not be affected by the provisions of this title." 73 Stat. 534 (1959), 29 U.S.C. $\$ 483$ (Supp. V, 1964). See, c.g., Beiso v. Robilotto, 26 Misc. 2d 137, 212 N.Y.S.2d 505 (Sup. Ct. 1960), Mamula v. United Steelworkers of America, 409 Pa. 175 (1962), sustaining state court jurisdiction in preelection suits. The Secretary's jurisdiction was made exclusive only in post-election cases. See the third sentence of $\S 403$ set out at note 12 supra. The legislative history indicates that the post-election remedy through the Secretary excluded only other postelection suits and not pre-election suits. The Senate report stated, "since the bill provides an effective and expeditious remedy for overthrowing an improperly held election and holding a new election, the federal remedy is made the sole remedy and private litigation would be precluded." S. REP. No. 187, 86th Cong., 1st Sess. 21 (1959).

53. Although the Court's language in Calhoon was confined to the jurisdiction of federal courts, its rationale would apply equally to bar the pre-election jurisdiction of state courts as well as federal courts where the conduct alleged arguably violated Title IV. In fact the only case cited by the majority in support for its rationale, Sun Diego Building Trades Council v. Garmon, 359 U.S. 236 (1959), cited at 379 U.S. 140, was a case which had arisen in the state courts. Admittedly the pre-election jurisdiction of the state courts is preserved by Title IV which contains a clause designed to save such jurisdiction. See note 52 supra. However, there have been situations in which the Court has denied a privately invoked judicial remedy notwithstanding the existence of a snvings clause. See, e.g., Texas \& Pacific R.R. v. Abilene Cotton Oil Co., 204 U.S. 426 (1907). The reasons which led the Court in Abilene to read the savings clause out of the statute were precisely the same which motivated the decision in Calhoon, i.e. a belief that the overriding purpose behind the statute would be frustrated by permitting private judicial remedies. Therefore in order to be consistent with Calhoon the Court would also have to bar state court jurisdiction.

54. 28 U.S.C. \& 1337 (1958). 
creates jurisdiction in the federal courts to enforce the substantive rights and duties created by a federal statute regulating commerce. ${ }^{65}$ Section 1337 has been used frequently as the basis for federal court jurisdiction when Congress has made no explicit provision for a private judicial remedy, even when there existed an administrative agency charged with enforcing the statute generally.:0 For example, in Tunstall v. Brotherhood of Locomotive Firemen and Engineers ${ }^{57}$ the Supreme Court sustained the jurisdiction ${ }^{\text {ts }}$ of a federal district court in a private suit to enforce a right created by the Railway Labor Act, notwithstanding the absence of a specific authorizing provision, and notwithstanding the existence of the National Mediation Board. Similarly in Fitzgcrald v. Pan American World Airways, 59 the Second Circuit allowed the plaintiff to allege damages caused by the discrimination of an airline in violation of the Civil Aeronautics Act, although Congress entrusted primary enforcement to the C.A.B. and did not specifically provide for individual suits. ${ }^{\text {CO }}$ In both cases

55. Hart \& Wechsler, The Federal Courts and the Federal Systeas 730-32 (1953). The congressional declaration of findings, purposes, and policy makes it clear that the LMRDA is an act of Congress regulating commerce. 73 Stat. 519 (1959), 29 U.S.C. § 401(c) (Supp. V, 1964). See MfcKeon v. Highway Drivers \& Helpers Local 107, 223 F. Supp. 341 (D. Del. 1963) ; AFL v. Watson, 327 U.S. 582 (1946).

56. In addition to the cases discussed in the text which follows, see St. Louis I. M. \& S. Ry. v. Taylor, 210 U.S. 281 (1908) (allowing private damage actions to employees injured by railroad's using equipment violating the Safety Appliance Act); Roosevelt Field v. Town of North Hempsted, 84 F. Supp. 456 (E.D.N.Y. 1949) (permilting a private suit to enjoin a water tower allegedly interfering with an airport); Reitmeister v. Reitmeister, 162 F.2d 691, 694 (2d Cir. 1947) (allowing civil actions for publishing telephone messages in violation of the duty imposed by the Communication Act of 1934); AFL v. Watson, 327 U.S. 582, 591 (1946) (permitting private suits to enjoin the interference by a state with rights granted by the National Labor Relations Act); Scrio v. Liss, 300 F.2d 386 (3d Cir. 1961) ; Neiswonger v. Goodyear Tire \& Rubber Co., 35 F.2d 761 (N.D. Ohio 1929). For a general discussion see Bunn, The National Law of Unfair Competition, 62 HAARv. L. REv. 987 (1949); Note, Federal Jurisdiction in Suits For Domages Under Statutes Not Affording Such Remedy, 48 CoLus. L. Rev. 1090 (1948).

57. 323 U.S. 210 (1944). Although Tunstall was a race discrimination case, the duty of fair representation has been sustained in economic discrimination cases under both the Railway Labor Act and Labor Management Relations Act. See, e.g., Ford Co. v. Huffman, 345 U.S. 330 (1953).

58. There has been a great deal of discussion as to whether the problem in these cases is one of jurisdiction or one of implying a cause of action. The Supreme Court has strongly urged the use of language which indicates the latter approach. Bell v. Hood, 327 U.S. 678 (1946). However, the lower federal courts have resisted. See, c.g., district court opinion in Harvey v. Calhoon, 221 F. Supp. 545, 550 (1963); Crawford v. Pituch, 91 F. Supp. 626 (W.D. Pa. 1950). See Note, Implying Cieril Rentedics From Federal Regulatory Statutes, 77 HaRv. L. Rev. 285, 289 (1963), concluding that this distinction is largely formalistic. Also the Supreme Court in Calhoon v. Harrey indieated that the distinction was irrelevant, 379 U.S. at 13. This Note adopts the terminology of jurisdiction to grant relief which hopefully incorporates both approaches.

59. $229 \mathrm{~F} 2 \mathrm{~d} 499,502$ (2d Cir. 1956).

60. Jurisdiction was sustained under either 28 U.S.C. $\$ 1337$ (1958) and 28 U.S.C. $\$ 1331$ (1958), the general "arising under" grant. The only difference between the twe 
the administrative agency could not grant the relief requested, and therefore the judicial remedy did not interfere with the agencies' powers or functions. ${ }^{\text {11 }}$ In Calhoon, also, the Secretary was not authorized to grant the pre-election relief requested. ${ }^{62}$ And in Calhoon, too, granting the private remedy would not interfere with the Secretary's function. ${ }^{63}$ Section 1337 would have been appropriately applied in that case. ${ }^{64}$

Nothing in the LMRDA's language or legislative history prevents the tuse of section 1337 to enforce Title IV rights. Congress did not consider the question of federal pre-election jurisdiction to enforce Title IV rights generally. of It has been argued, however, that since Congress specifically granted jurisdiction in section 401 (c) when an individual member sues to force distribution of provisions with regard to a statute regulating commerce is that $\S 1331$, unlike $\& 1337$, requires $\$ 10,000$ as a jurisdictional amount. 1 Moore, Federai. Practice $\llbracket 0.60$ [8.-3], at 627 (2d ed. 1959).

61. Cf. Montana-Dakota Util. Co. v. Northwestern Pub. Serv. Co., 341 U.S. 246 (1951), denying a private remedy because it would interfere with the administratvie procedures established by Congress. See generally Note, Implying Civil Remedics From Federal Regulatory Statutes, 77 HaRv. L. Rev. 285, 291 (1963).

62. A union member cannot go to the Secretary of Labor until the election has been conducted. See note 14 supra.

63. See the discussion of the Secretary's function supra notes 29-33 and accompanying text.

64. Admittedly the decision in Calhoon, excluding pre-election remedies under Title IV, is consistent with prior decisions of the majority of the lower federal courts which considered this question. See, e.g., Mamula v. United Steelworkers of America, $205 \mathrm{~F}$. Supp. 913 (W.D. Pa. 1962); Fogle v. United Steelworkers of America, 230 F. Supp. 797 (W.D. Pa. 1964) ; Colpo v. Highway Truck Drivers Local 107, 201 F. Supp. 307 (D. Del. 1961) ; Johnson v. San Diego Waiters \& Bartenders Union Local 500, $190 \mathrm{~F}$. Supp. 444 (S.D. Cal. 1961) ; Boling v. International Bhd. of Teamsters, 224 F. Supp. 18 (E.D. Tenn. 1963) ; Byrd v. Archer, 45 L.R.R.M. 2289 (S.D. Cal. 1960) ; dictum in Gammon v. International Ass'n of Machinists, 199 F. Supp. 433 (N.D. Ga. 1961) (dictum); but cf. the decision of the Second Circuit in Harvey v. Calhoon, 324 F.2d 486, 490 (1963), leaving the question open. Mr. Justice Stewart, concurring in Calhoon, 379 U.S. 146, concluded that, "As to the federal courts, it is certainly arguable that recourse through the Secretary of Labor is the exclusive remedy only after the election has been held." Also in McKeon v. Highway Drivers \& Helpers Local 107, 223 F. Supp. 341 (D. Del. 1963), the court concluded that since the Secretary of Labor did not have jurisdiction to bring a suit to compel the election of the office in question, the private judicial remedies were appropriate under $\S 1337$ notwithstanding the absence of a specific congressiontal authorization in the LMRDA for such suits. However, of the cases cited in this footnote which rejected jurisdiction, only two of these mentioned $\S 1337$ in their opinions.

65 . It has been argued that $\S 603$ (a) providing that, "Except as explicitly provided to the contrary, nothing in this Act shall take away any right or bar any remedy to members of a labor organization are entitled under such other Federal law or law of any State," 73 Stat. 540 (1959), 29 U.S.C. \& 523(a) (Supp. V, 1964), atthorizes federal jurisdiction. See McKeon v. Highway Truck Drivers \& Helpers Local 107, 223 F. Supp. 341, 344 (D. Del. 1963) ; Colpo v. Highway Truck Drivers \& Helpers Local 107, 201 F. Supp. 307, 313 (D. Del. 1961). However $\$ 603$ (a) was actually intended to be only a general anti-pre-emption provision and not a source of new rights. See DeVeat v. Braisted, 363 U.S. 144 (1959). 
campaign literature, ${ }^{66}$ it meant to exclude jurisdiction in all other cases. ${ }^{67}$ This argument has no support in the legislative history, which indicates that section 401 (c) was drafted separately and was added as an amendment to the original bill during debate in the Senate without consideration of the remedies to enforce other Title IV rights. ${ }^{68}$ Since there is no indication that Congress considered the right to distribute campaign literature superior to other Title IV rights, ${ }^{\text {e9 }}$ section 401 (c) ought not prevent giving equally effective remedies to more important rights through application of section $1337 . .^{70}$

The use of section 1337 is also required in order to avoid the anomaly that federal courts would not be able effectively to enforce Title IV rights, but state courts would. Congress preserved pre-existing state court jurisdiction to hear pre-election cases in the second sentence of section 403 of the Act. ${ }^{71}$ Although the words of the section seem to require the application of state substantive law, the legislative history makes clear that this section was meant only to maintain the state courts as fora, and not to dictate the state courts' choice of applicable law. ${ }^{72} \mathrm{~A}$ consideration of the possible alternatives seems to compel the application of the Title IV provisions.

A state court could either: (1) apply state substantive law without regard to the union constitution or the LMRDA; (2) enforce the union constitution according to state law, but still without regard to the LMRDA; (3) enforce union constitutional provisions if they are not inconsistent with the LMIRDA, ${ }^{73}$

66. 73 Stat. 532 (1959), 29 U.S.C. \& 481(c) (Supp. V. 1964).

67. The Court seems to accept this argument in Calhoon, 379 U.S. at 140.

68. 105 CoNG. REC. 6727-29 (1959). The language of $\S 401(\mathrm{c})$ also indicates that it may have been added to insure standing rather than jurisdiction.

69. See Summers, Pre-Emption and the Labor Reform Act - Dual Rights and Remedies, 22 Oнго Sт. L.J. 119, 137 (1961).

70. Given the jurisdiction of the federal courts to enforce the federal substantive rights created by Title IV of the LMRDA, clearly a court can issue an injunction as an appropriate remedy. "It is well settled that when legal rights have been invaded, and a federal statute provides for a right to sue for such an invasion, federal courts may use any available remedy to make good the wrong done." Bell v. Hood, 327 U.S. 678, 684 (1946). For cases holding an injunction appropriate where jurisdiction was founded under \$1337, see Mulford v. Smith, 307 U.S. 38 (1939); AFL v. Watson, 327 U.S. 582 (1946).

71. See note 52, supra.

72. "The central purpose of the second sentence of Section 403 was to keep available prompt pre-election remedies, not to preserve state substantive law." Summers, Pre-cmplion and the Labor Reform Act-Dual Rights and Remedies, 22 Onıo St. L.J. 119, 137 (1961). This conclusion accords with the intent of those responsible for the language of $\S 403$ (as enacted) to preserve only the pre-election jurisdiction of the state courts and not state substantive law. See note 51 supra. See also the dictum of Mr. Justice Frankfurter in DeVeau v. Braisted, 363 U.S. 144, 156 (1960), that $\S 403$ is an "express provision cxciuding the operation of state law."

73. This third source of law has been incorporated by reference into the federal rights created by Title IV. The last sentence of $\$ 401$ (e) provides, "the election slaall be conducted in accordance with the constitution and bylaws of such organization insofar as they are not inconsistent with the provisions of this title" 73 Stat. 533 (1959), 29 U.S.C. $\S 481$ (e) (Supp. V, 1964). 
or (4) enforce the entire range of Title IV rights. The first possibility conflicts with Congress' desire to replace the unions' diverse obligations under state laws with a uniform federal obligation. ${ }^{74}$ The second possibility must be rejected because it leads to a possible conflict between duties imposed by state and federal law. ${ }^{\mathbf{7 5}}$ For example, a union constitution may require the election of officers by a show of hands in violation of the LMRDA's secret ballot provisions. ${ }^{76}$ If the union follows its constitution in violation of federal law, the election may be set aside in a post-election suit. If the union plans to conduct an election by secret ballot in violation of its constitution, the election may be enjoined by the state court. The third possibility leaves a union member with less protection than he had before the enactment of the LMRDA, since before the Act state courts often went beyond the provisions of the union constitution and bylaws in granting effective pre-election relief. ${ }^{77}$ Moreover, a union could avoid the law completely by simply amending its constitution and bylaws. Only the fourth possibility is consistent with the general congressional intent. ${ }^{78} \mathrm{Un}$ like the other choices, it imposes uniform obligations upon the union adequate

74. The first sentence of $\S 403$ provides that, "No labor organization shall be required by law to conduct elections of officers with greater frequency or in a different form or manner than is required by its own constitution or bylaws, except as otherwise provided by this title." 73 Stat. 534 (1959), 29 U.S.C. $\S 483$ (Supp. V, 1964). The Committee Report in the Senate explained the inclusion of this sentence in the following manner:

There is great need for uniformity in the laws governing union elections. International and national unions operate in many States. It would be confusing, unduly burdensome, often impossible for them to comply with a variety of election laws. The same considerations apply, with somewhat lesser force, to local unions, a considerable number of which function in several States. Also, the burden of checking compliance will fall upon the international union. It is easier to enforce one uniform rule than a crazy quilt of state legislation and court decisions. Ill-considered State laws would interfere with the national labor policy. Too stringent laws wotld handicap unions in dealing with employers. Too frequent elections may keep a union in a state of turmoil and could result in instability in collective bargaining relationships with employers.

Senate REp. No. 187, 86th Cong., 1st Sess. 21-22 (1959).

75. For a detailed analysis of the problem of determining when federal law has pre-empted state law in the labor field with particular emphasis upon the conflicting duties imposed by federal and state law, see Wellington, Labor and the Federal Systcm, 26 U. CHI. L. REv. 542 (1959).

76. A secret ballot is required for all local and international elections. 73 Stat. 532 (1959), 29 U.S.C. $\S 481$ (a), (b) (Supp. V, 1964). For the definition of a secret ballot see 73 Stat. 521 (1959), 29 U.S.C. $\$ 402$ (k) (Supp. V, 1964).

77. See, e.g., Lacey v. O'Rourke, 147 F. Supp. 922 (S.D.N.Y. 1956); Di Bucci v. Uhrich, 21 Misc. 2d 1069, 189 N.Y.S.2d 717 (Sup. Ct. 1959); Sibilia v. Western Elec. Employees Ass'n, 142 N.J. Eq. 77, 59 A.2d 251, 253 (1948). See generally Summers, Jndicial Regulation of Union Elections, 70 YALE L.J. 1221, 1249 (1961).

78. The argument that different state courts will construe these federal rights in different ways is not particularly troublesome. The United States Supreme Court may always review the decision of the highest state court in these cases under 28 U.S.C. $\$ 1257$ (1958). 
to protect the individual members. If a state court is to enforce the entire range of Title IV rights before the election, there is no justification for preventing a : federal court from enforcing them, especially since the federal courts are the "primary [fora] for the vindication of federal rights."70

Even if the Calhoon Court was not willing to use section 1337, it could have sustained federal pre-election jurisdiction by finding that plaintiff alleged a Title I violation. Since there is no reason to allow the Secretary's post-election functions to limit pre-election relief, 80 the Court could have construed Title I broadly in order to make the "equal right ... to nominate"s1 effective. To make this right effective, though, it is absolutely necessary that eligibility requirements be considered. ${ }^{82}$ For example, in Calhoon itself, although all members could nominate, the limitation on candidacy made many of the nominations useless. Under Calhoon, a union could violate Title I only by excluding a class of members from going through the physical act of nominating. ${ }^{83}$ But the union's motivation for preventing a class from nominating would be to exclude

79. Hart \& Wechsler, The Federal Courts and the Federal Systear 727 (1953). This anomaly is underscored by the fact that state courts would be enforcing these federal rights and federal courts could only provide the shelter of a federal forum if diversity existed. 28 U.S.C. § 1332. See Mamula v. Local 1211 United Steelworkers of America, 205 F. Supp. 913 (W.D. Pa. 1962) ; Byrd v. Archer, 45 L.R.R.AL 2289 (S.D. Cal. 1959). Of course Congress is partially to blame because of its sloppy draftsmanship. Nevertheless the Court should not reach such an anomalous result unless the words of the statute clearly require it.

80. See notes 29-33 supra and accompanying text.

81. See note 11 supra.

82. "The right to nominate can be infringed by restrictions on eligibility for office as well as by rules dealing directly with the right to nominate" Libutti v. DiBrizzi, 337 F.2d 216, 218 (2d Cir. 1964). See also the Second Circuit's opinion in Harvey v. Calloon. 324 F.2d 486 (1963). Unlike the Second Circuit, most lower courts refused to consider eligibility requirements in a suit by a union member under Title I. Mamula v. Local 1211, United Steelworkers of America, 304 F.2d 108 (3d Cir. 1962); MFamula v. United Steelworkers of America, 205 F. Supp. 913 (W.D. Pa. 1962); Colpo v. Highway Truck Drivers Local 107, 201 F. Supp. 307 (D. Del. 1961); Johnson v. San Diego Waiters \& Bartenders Union, 190 F. Supp. 444 (S.D. Cal. 1961); Gammon v. International Ass'n of Machinists, 199 F. Supp. 433 (N.D. Ga. 1961); Jackson v. International Longshoremen's Ass'n, 212 F. Supp. 79 (E.D. La. 1962) ; Boling v. International Bhd. of Teamsters, 224 F. Supp. 18 (E.D. Tenn. 1963); Sanders v. Local 559, 54 L.R.R.M. 2234 (W.D. Ky. 1963) ; Byrd v. Archer, 45 L.R.R.MI. 2289 (S.D. Cal. 1959). The remarkable thing about these cases is that the basis for dismissal in almost all of them was that Title I did not give a right of action to the nominee but only to the member who made the nomination. Even if the courts were correct in insisting upon this formal requirement, it should be easily satisfied if the nominator initiates a separate suit or if the nominee joins the nominator. 3 Moore, Federar. Practice, II 20.05 (2d ed. 1964). However, for some reason plaintiffs' lawyers have been very slow to pursue either of these courses.

83. Mr. Justice Stewart's concurring opinion in Calhooss rejected the majority's interpretation, pointing out that under this view no member could claim a violation of his right to nominate if the union issued a regulation that only the incumbent officers were eligible for office. 379 U.S. at 143. 
that class' nominees. The union could easily avoid Calhoon by allowing everyone to nominate, but by refusing to put certain nominees on the ballot, or by disqualifying them through the application of unreasonable eligibility requirements. ${ }^{84}$ In short, unless eligibility requirements are considered relevant to a Title I claim, the "equal right . . . to nominate" disappears. ${ }^{80}$

On both the Title I and Title IV questions Calhoon v. Harvey was wrong. However, the responsibility for the decision must be shared by the legislature. Congress superimposed, without reconciling, two titles, which overlapped in substantive rights and differed in schemes of enforcement. Yet the final responsibility must rest with the courts, which have an obligation to construe the statute in accordance with its major purpose. The Calhoon Court failed to meet this obligation.

Allan J. TopoL*

84. Under Calhoon the excluded class has not been deprived of Title I rights since all members have an equal right to nominate the majority's candidates.

85. This Note does not consider which eligibility requirements are unreasonable. In Calhoon itself Justices Stewart, Harlan, and Douglas accepted the broad interpretation of Title $I$ to include eligibility requirements. However, Justices Stewart and Harlan concluded that the restrictions drawn in question were not unreasonable. 379 U.S. at 146.

*LL.B. 1965, Yale University. 